\title{
A new species of Brasilotyphlus (Gymnophiona: Siphonopidae) and a contribution to the knowledge of the relationship between Microcaecilia and Brasilotyphlus
}

\author{
LARISSA LIMA CORREIA ${ }^{1,2,7}$, PEDRO M. SALES NUNES ${ }^{1}$, TONY GAMBLE ${ }^{3}$, \\ ADRIANO OLIVEIRA MACIEL ${ }^{4}$, SERGIO MARQUES-SOUZA ${ }^{5}$, ANTOINE FOUQUET ${ }^{6}$, \\ MIGUEL TREFAUT RODRIGUES ${ }^{5} \&$ TAMÍ MOTT $^{2}$ \\ ${ }^{1}$ Universidade Federal de Pernambuco, Centro de Biociências, Departamento de Zoologia/Programa de Pós-Graduação em Biologia \\ Animal, Av. Professor Moraes Rego, s/n. 50670-901, Recife, PE, Brazil \\ ${ }^{2}$ Universidade Federal de Alagoas, Setor de Biodiversidade, Av. Lourival Melo Mota, s/n, Tabuleiro, 57072-970, Maceió, AL, Brazil \\ ${ }^{3}$ Department of Biological Sciences, Marquette University, Milwaukee, Wisconsin USA \\ ${ }^{4}$ Programa de Capacitação Institucional, Museu Paraense Emilio Goeldi, Coordenação de Zoologia. Av. Perimetral 1901, Terra \\ Firme, CEP 66077-830, Belém, PA, Brazil. \\ ${ }^{5}$ Departamento de Zoologia, Universidade de São Paulo, São Paulo, Rua do Matão, São Paulo 05422-970, Brazil \\ ${ }^{6}$ Laboratoire Ecologie, Evolution, Interactions des Systèmes Amazoniens (LEEISA), \\ USR3456, Cayenne, French Guiana. \\ ${ }^{7}$ Corresponding author. E-mail: larissalcorreia@hotmail.com
}

\begin{abstract}
A third species of Brasilotyphlus, a siphonopid caecilian, is described based on six specimens from two twin mountains in Roraima state, northern Brazil. Brasilotyphlus dubium sp. nov. differs from all other congeners in having a combination of 123-129 primary annuli and 9-16 secondary annular grooves. The first molecular data were generated and analyzed for Brasilotyphlus, and the genus was recovered as monophyletic and nested within a paraphyletic Microcaecilia. The extent of genetic and taxon sampling, and levels of phylogenetic support are not considered sufficient enough to place Brasilotyphlus in the synonymy of Microcaecilia.
\end{abstract}

Key words: Brazil, caecilians, phylogeny, taxonomy

\section{Introduction}

Brasilotyphlus Taylor 1968 is a Brazilian endemic genus of caecilian amphibian (Gymnophiona), first described to accommodate Gymnopis braziliensis Dunn 1945 from Manaus municipality, Amazonas. Currently, B. braziliensis (Dunn 1945) is known only from its type locality and Reserva do Gavião ( $02^{\circ} 25^{\prime} \mathrm{S}, 5^{\circ} 50^{\prime} \mathrm{W}$ ), approximately 70 $\mathrm{km}$ from Manaus (Maciel \& Hoogmoed 2011). Four decades after Taylor's work, a second species of the genus, $B$. guarantanus Maciel, Mott and Hoogmoed 2009, was described from Guarantã do Norte municipality in the state of Mato Grosso and Parauapebas municipality, state of Pará, Brazil (Maciel et al. 2009). In the most recent comprehensive taxonomic overview of Gymnophiona, Brasilotyphlus was diagnosed by a unique combination of morphological characters within Siphonopidae of a diastema between the vomerine and palatine teeth and eyes covered by bone (Wilkinson et al. 2011). Wilkinson \& Nussbaum (2006), Maciel et al. (2009) and Maciel \& Hoogmoed (2011) argued that Brasilotyphlus is very similar to Microcaecilia, the most species-rich genus of siphonopid caecilian. Considering that the diastema is the main difference between these genera, Maciel et al. (2009) and Maciel \& Hoogmoed (2011) questioned whether the two genera are valid entities or should be considered synonymous. However, Wilkinson et al. (2013) highlighted that the difference between Microcaecilia and Brasilotyphlus is more complex, because the diastema in Brasilotyphlus is large and associated with three other characters: palatine series extending posteriorly slightly further than premaxillary-maxillary series; semicircular 
vomerine series; and relatively posterior choanae. One approach to testing the reciprocal monophyly of these two genera would be to use molecular data, however such data are not available for Brasilotyphlus.

During two expeditions to the Serra do Apiaú and Serra da Maroquinha, two isolated granitic massifs in Mucajaí municipality, state of Roraima, northern Brazil, some of us (AF, PMSN and SMS) and colleagues found five specimens of an undescribed species of a siphonopid caecilian. Subsequently, an additional specimen deposited in the herpetological collection of the Museu Paraense Emilio Goeldi (Coleção Herpetológica Osvaldo Rodrigues da Cunha, MPEG), Belém, Pará, Brazil, was also identified as the same putative species. Here we describe this as a third species of Brasilotyphlus, from c. $620 \mathrm{~km} \mathrm{NW}$ from the type locality of B. braziliensis and $1,500 \mathrm{~km} \mathrm{NW}$ from the type locality of B. guarantanus (Figure 1). Moreover, we provide the first molecular assessment of the systematics of Brasilotyphlus.

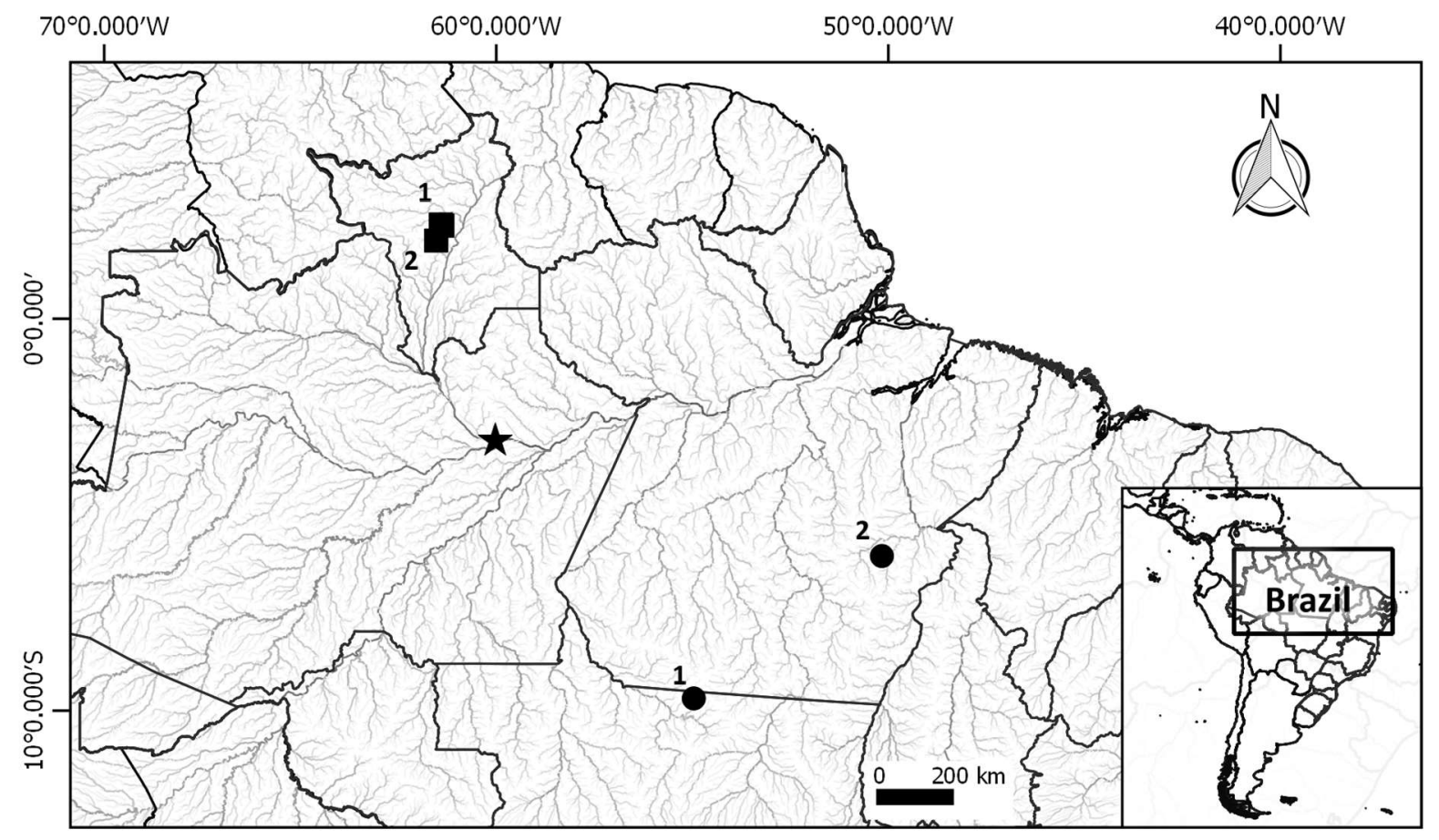

FIGURE 1. Map showing the distribution of Brasilotyphlus: star represents the type locality of B. braziliensis [Manaus, Amazonas, Brazil (Dunn 1945)]; circle 1 is the type locality of B. guarantanus [Municipality of Guarantã do Norte, Mato Grosso, Brazil (Maciel et al. 2009)]; circle 2 is the paratype locality of B. guarantanus [Municipality of Parauapebas, Pará, Brazil (Maciel et al. 2009)]; square 1 is the type locality of Brasilotyphlus dubium sp. nov. [Municipality of Mucajaí, Roraima, Brazil (this study)]; square 2 is the locality of a Brasilotyphlus dubium sp. nov. paratype [MPEG 7779; Municipality of Iracema. Roraima, Brazil (this study)].

\section{Material and methods}

Morphological data. Six collected specimens were investigated based on nine meristic and 16 morphometric characters. We used the respective abbreviations for morphological characters following Maciel \& Hoogmoed (2011) and for anatomy of the nuchal region following Kamei et al. (2009). TL—total length; HH—head height at level of corner of mouth; HL-head length, measured from tip of snout to posterior edge of skull (felt through the skin of the dorsal surface of the collar region); HW - head width at corner of mouth; BH—body height at midbody; BW — body width at midbody; WTR — body width at five primary folds anterior to the vent; SP — distance between snout tip and anterior margin of mouth; TMM — distance between tentacle and margin of mouth; TCM — distance between tentacle and corner of mouth; TN—distance between tentacle and nostril; TT—shortest distance between opposite tentacles; $\mathrm{NN}$ - shortest distance between opposite nostrils; NCM-distance between nostril and corner of mouth; NMM-distance between nostril and margin of mouth; HWN-head width at level of nostrils; 
AIV — primary annular grooves interrupted by vent; CSG — secondary annular grooves completely encircling body; CPA - primary annular grooves completely encircling body; PA - primary annuli; SG—secondary grooves (= number of primary annuli bearing secondary grooves); DT — dentary teeth; PMT — premaxillary-maxillary teeth; PVT - prevomerine teeth; PT — palatine teeth; NG1 - first nuchal groove (between head and collars); NG2second nuchal groove (between first and second collars); NG3 - third nuchal groove (between collars and anteriormost annulus). Dermal and subdermal scales were examined following Wilkinson et al. (2013).

TABLE 1. Sequences of Gymnophiona used in this study. Taxa, voucher numbers and NCBI GenBank accession numbers. *from this study.

\begin{tabular}{|c|c|c|c|}
\hline Terminal taxa & Voucher & 16SrRNA & Cytb \\
\hline Brasilotyphlus guarantanus 1 & MUFAL10363 & MG162597* & MG162605* \\
\hline Brasilotyphlus guarantanus 2 & MUFAL10379 & MG162598* & MG162606* \\
\hline Brasilotyphlus guarantanus 3 & UFMT5009 & MG162599* & - \\
\hline Brasilotyphlus guarantanus 4 & UFMT5012 & MG162600* & - \\
\hline Brasilotyphlus dubium sp. nov. 1 & MUFAL13638 & MG162601* & MG162607* \\
\hline Brasilotyphlus dubium sp. nov. 2 & MUFAL13639 & MG162602* & MG162608* \\
\hline Brasilotyphlus dubium sp. nov. 3 & MUFAL13641 & MG162603* & MG162609* \\
\hline Boulengerula fischeri & BMNH 2008.607 & FR691661 & FR691666 \\
\hline Boulengerula taitanus & NMK A/3112 & AY954504 & AY954504 \\
\hline Caecilia gracilis & BMNH:2008.747 & KF540147 & KF540147 \\
\hline Caecilia tentaculata & BMNH:2008.750 & KF540146 & KF540146 \\
\hline Chikila fulleri & BNHS 5514 & NC_021369 & NC_021369 \\
\hline Crotaphatrema lamottei & BMNH:2008.274 & NC019596 & NC019596 \\
\hline Dermophis mexicanus & No voucher & KF540150 & KF540150 \\
\hline Gegeneophis ramaswamii & MW 331 & AY456250 & AY456250 \\
\hline Gegeneophis seshachari & BNHS:4601 & HQ444015 & HQ444103 \\
\hline Geotrypetes seraphini 1 & MVZ 252475 & GQ244469 & GQ244469 \\
\hline Geotrypetes seraphini 2 & BMNH 2005.2 & AY954505 & AY954505 \\
\hline Gymnopis multiplicata 1 & MVZ:Herp:179536 & NC020139 & NC020139 \\
\hline Gymnopis multiplicata 2 & MVZ 171331 & GQ244471 & GQ244471 \\
\hline Ichthyophis glutinosus & MW 1733 & AY456251 & AY456251 \\
\hline Luetkenotyphlus brasiliensis & BMNH:2005.3 & KF540158 & KF540158 \\
\hline Microcaecilia dermatophaga & BMNH:2008.716 & KF540159 & KF540159 \\
\hline Microcaecilia sp1. & MTR20960 & MG162604 * & MG162610 * \\
\hline Microcaecilia savagei & MAD 496 & EU753992 & EU754004 \\
\hline Microcaecilia sp2. & IWK 0128 & GQ244473 & GQ244473 \\
\hline Microcaecilia sp2. & No voucher & EU753993 & EU754005 \\
\hline Microcaecilia unicolor & BMNH:2008.749 & KF540160 & KF540160 \\
\hline Rhinatrema bivittatum & BMNH 2002.6 & AY456252 & AY456252 \\
\hline Rhinatrema shiv & IRSNB:1991 & GU566189 & GU566190 \\
\hline Schistometopum gregorii & BMNH:2008.559 & KF540163 & KF540163 \\
\hline Schistometopum thomense & CAS 219292 & GQ244476 & GQ244476 \\
\hline Scolecomorphus vittatus & BMNH 2002.100 & AY456253 & AY456253 \\
\hline Siphonops annulatus 1 & BMNH 2005.9 & NC007911 & NC007911 \\
\hline Siphonops annulatus 2 & MVZ 162588 & EU753986 & EU754003 \\
\hline Typhlonectes natans 2 & No voucher & NC002471 & $\mathrm{NC} 002471$ \\
\hline Typhlonectes natans 1 & FC 13178 & EU753984 & EU753999 \\
\hline
\end{tabular}


Comparisons with B. braziliensis were made using only the literature (Taylor 1968; Maciel \& Hoogmoed 2011) and with B. guarantanus using two specimens from Parauapebas, Pará, Brazil (Museu de História Natural da Universidade Federal de Alagoas, MUFAL 10363; 10379) and literature data (Maciel et al. 2009). A small ventral incision was made and all specimens were sexed by direct examination of the gonads. Specimens were classified as immature when gonads could not be clearly differentiated.

Molecular data. New molecular genetic data were generated from seven specimens including three specimens of the new species (MUFAL 13638, 13639, 13641) and four B. guarantanus, two from the type locality, Guarantã do Norte, Mato Grosso (Universidade Federal de Mato Grosso, UFMT 5009 and the paratype UFMT 5012), and two specimens from the paratype locality, Parauapebas, Pará, ca. $661 \mathrm{~km}$ from type locality (MUFAL 10363, $6^{\circ} 3^{\prime}$ $8^{\prime \prime} \mathrm{S}, 50^{\circ} 7^{\prime} 40^{\prime \prime} \mathrm{W}$; and $\left.10379,6^{\circ} 3^{\prime} 29^{\prime \prime} \mathrm{S}, 50^{\circ} 11^{\prime} 50^{\prime \prime} \mathrm{W}\right)$. Total genomic DNA was extracted using a salt precipitation method (Fetzner 1999). Fragments of two mitochondrial genes (cytochrome b and 16SrRNA) were amplified and sequenced using the primers MNCN-Glu and CytB (San Mauro et al. 2004), and 16sar and 16sbr (Palumbi et al. 1991) respectively. PCR and sequencing protocols used were those developed by San Mauro et al. (2004) for caecilians. All sequences were edited and assembled using the default settings in Bioedit v.7.2.5 (Hall 1999), sequences of cytochrome b were additionally translated into amino acids for confirmation of alignment. To infer the phylogenetic placement of the new species and that of $B$. guarantanus, sequences of cytochrome $b$ and 16SrRNA from 37 species of caecilians representing all ten families for which homologous sequences were available in Genbank and including all siphonopid species (accession numbers available in Table 1) were downloaded and incorporated in the data matrix. The 16SrRNA and cytochrome $\mathrm{b}$ alignments are deposited on TreeBASE (http://purl.org/phylo/treebase/phylows/study/TB2:S22971).

We identified the best-fitting substitution models for each gene using jModeltest 2.1.7 (Posada 2008) with the Akaike information criterion (AIC). The best-fit substitution model was TIM2 $+\mathrm{I}+\mathrm{G}$ for $16 \mathrm{srRNA}$ and TPM3 $\mathrm{uf}+\mathrm{I}+\mathrm{G}$ for cytochrome $\mathrm{b}$, however, because these models are not implemented in MrBayes 3.4.5 (Huelsenbeck \& Ronquist 2001), the GTR $+\mathrm{I}+\mathrm{G}$ model was implemented for the concatenated dataset. Bayesian analyses were conducted with a concatenated matrix using MrBayes 3.4.5 (Huelsenbeck \& Ronquist 2001). In order to explore parameter space thoroughly, we implemented four incrementally heated Metropolis-coupled Markov chains Monte Carlo (MCMC), using random trees as an initial step for chains, and ran them for 20 million generations each, sampling every 1,000 generations. Because higher ESS values indicate lower standard errors, MCMC sampling was considered adequate if the effective sampling size (ESS) for each parameter was higher than 200 and if the standard deviation of the split frequencies was lower than 0.01 , both checked using Tracer v1.6 (Rambaut et al. 2014). The first $25 \%$ of the samples were discarded as burnin. Analyses were summarized with a $50 \%$ majority rule consensus. The reliability of each node was evaluated based on the posterior probability (PP) in the Bayesian analysis.

We tested the reciprocal monophyly of Brasilotyphlus and Microcaecilia in a maximum likelihood (ML) phylogenetic framework using the Approximately Unbiased (AU) test (Shimodaira 2002). We compared the optimal maximum likelihood tree to the ML tree in which all sampled Microcaecilia were enforced as monophyletic. ML phylogenies were constructed using RAxML 8.2.10 (Stamatakis 2014) on the CIPRES Science Gateway (Miller et al. 2010). Data were partitioned by gene, and nodal support estimated using rapid bootstrapping (Stamatakis et al. 2008), which was stopped automatically after 102 replicates. The AU test was implemented in PAUP* v4.0a161 (Swofford 2003) with likelihood scores estimated using the GTR+G+I model and p-values generated using 10,000 RELL bootstrap replicates.

\section{Results}

Brasilotyphlus dubium sp. nov.

Figs. 2-4; Table 2

Holotype. Museu de História Natural da Universidade Federal de Alagoas (MUFAL) 13638, field number MTR 23151, a male collected by Pedro M. Sales Nunes, Antoine Fouquet and Felipe Franco Curcio, from Serra da Maroquinha (N 2 22' 44", W 61²2' 37"), 400 m from sea level, Mucajaí municipality, Roraima, Brazil, May 2012. 
Paratypes $(\mathbf{n}=\mathbf{5})$. MUFAL 13639, male, field number MTR 23216, collected in pitfall trap, with same collection data as the holotype; MUFAL 13640, field number SMS 873, immature, MUFAL 13641, field number SMS 920, female, and MUFAL 13642, field number SMS 940, female, collected by Sergio Marques de Souza, Pedro M. Sales Nunes and Antoine Fouquet, from Serra do Apiaú (N 2 24' 30", W 61 24' 54") at 140 m, 685 m and $835 \mathrm{~m}$ from sea level respectively, state of Roraima, Brazil, in November 2011; and MPEG 7779, female, collected by Laurie J. Vitt, from $7 \mathrm{~km}$ east of the Ajarani river (N $\left.1^{\circ} 59^{\prime} 50^{\prime \prime}, \mathrm{W} 61^{\circ} 32^{\prime} 4^{\prime \prime}\right)$, Iracema municipality, Roraima, Brazil, 3 July 1993.

Identification. The new species is considered a species of Brasilotyphlus on the basis of it having eyes covered by bone and a diastema between the vomerine and palatine teeth with the following associated characters: palatine extends posteriorly to the series of premaxillary-maxillary teeth; a semicircular vomerine series of teeth.

Diagnosis. Brasilotyphlus dubium sp. nov. differs from B. braziliensis in having fewer primary and secondary annular grooves (123-129 and 9-16 vs 142-147 and 23-36, respectively), and in having premaxillary-maxillary teeth reaching the level of the posterior edge of the choanae (in B. braziliensis the maxillary teeth do not reach the level of the choanae). The new species differs from $B$. guarantanus in having fewer primary annuli (123-129 vs 151-170) and more secondary annular grooves (9-16 vs $0-2)$.

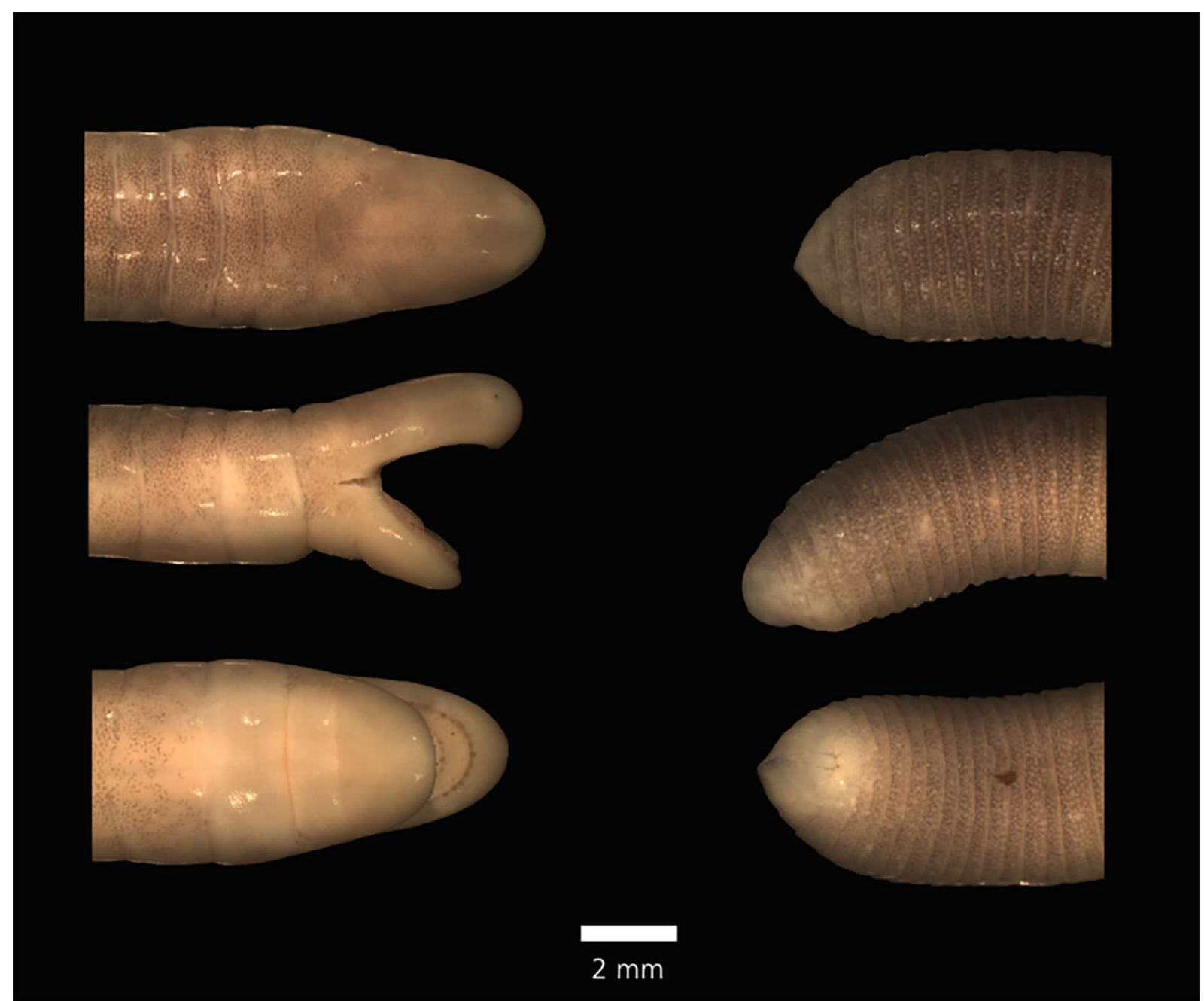

FIGURE 2. MUFAL 13638, holotype of Brasilotyphlus dubium sp. nov. from Serra da Maroquinha, Roraima, Brazil. Left column: head and anterior part of body in dorsal (above), lateral (middle) and ventral view (below). Right column: posterior part of body in dorsal (above), lateral (middle) and ventral view (below).

Description of the holotype. Morphometric and meristic data are in Table 2. Specimen in good condition, a $3.7 \mathrm{~mm}$ midventral incision and slightly broken corners of the mouth. Body subcylindrical, slightly flattened dorsoventrally throughout (BW x BH $3.9 \times 2.9 \mathrm{~mm}$ ), slightly narrower anteriorly and posteriorly (WTR $3.6 \mathrm{~mm}$ ). In dorsal view, head intermediate between U- and V-shaped. In lateral view, top of head slightly convex; upper lip 
slightly concave at the anterior end and lower lips straight. Snout projects strongly beyond recessed mouth (SP 1 $\mathrm{mm}$ ). Eyes not visible. Tentacles slightly elevated and not visible from above, closer to the corner of the mouth (TCM $1.3 \mathrm{~mm}$ ) than to nares (TN $1.6 \mathrm{~mm}$ ). Nares visible from above, but not from below. Teeth pointed and gently recurved. Premaxillary-maxillary teeth monocuspid, forming a series (21 teeth) with posterior maxillary teeth slightly smaller, extending to the level of the posterior edge of the choanae. Nine prevomerine and 10 palatine bicuspid teeth, with no apparent variation in size, smaller than those of the premaxillary-maxillary series and with a large diastema between them, which corresponds to a distance of approximately three tooth positions. Dentary teeth monocuspid, forming a series of 13 teeth, posterior ones slightly smaller, larger than those of premaxillarymaxillary series. Subcircular choanal apertures, separated by an approximate distance of 1.5 times the width of each choanal aperture, anterior edges approximately level with tentacles. Two collars clearly marked by three nuchal grooves (NG1, NG2, and NG3); NG1 and NG2 completely encircling the body, NG3 incomplete, curving posteriorly on the venter. In dorsal view, NG1 straight, NG2 slightly curved anteriorly, and NG3 straight; first collar smaller than second. In ventral view, NG1 curved anteriorly, NG2 straight and NG3 slightly incomplete and curved posteriorly; first and second collar similar in size. NG1 oblique laterally. A conspicuous transverse groove is present on the dorsolateral surface of the second collar. Following collars, 125 PAs, being 123 complete and two interrupted by the vent; First SG short, dorsally located on 112th PA; SGs complete from $119^{\text {th }}$ PA. Vent with six main denticulations and some irregular subdivisions, the interdenticular creases shorter anteriorly. Dorsally, body terminus strongly convex. Distinct vertical terminal keel present. Annular scales limited to a single and incomplete row in the 92th groove of scales wider than long (e.g., $0.1 \times 0.2 \mathrm{~mm}$ ); in a single incomplete row at 107 th groove (e.g., $0.1 \times 0.3 \mathrm{~mm}$ ) and in a complete row of ovate scales at 120 th groove (e.g., $0.4 \times 0.8 \mathrm{~mm}$ ).

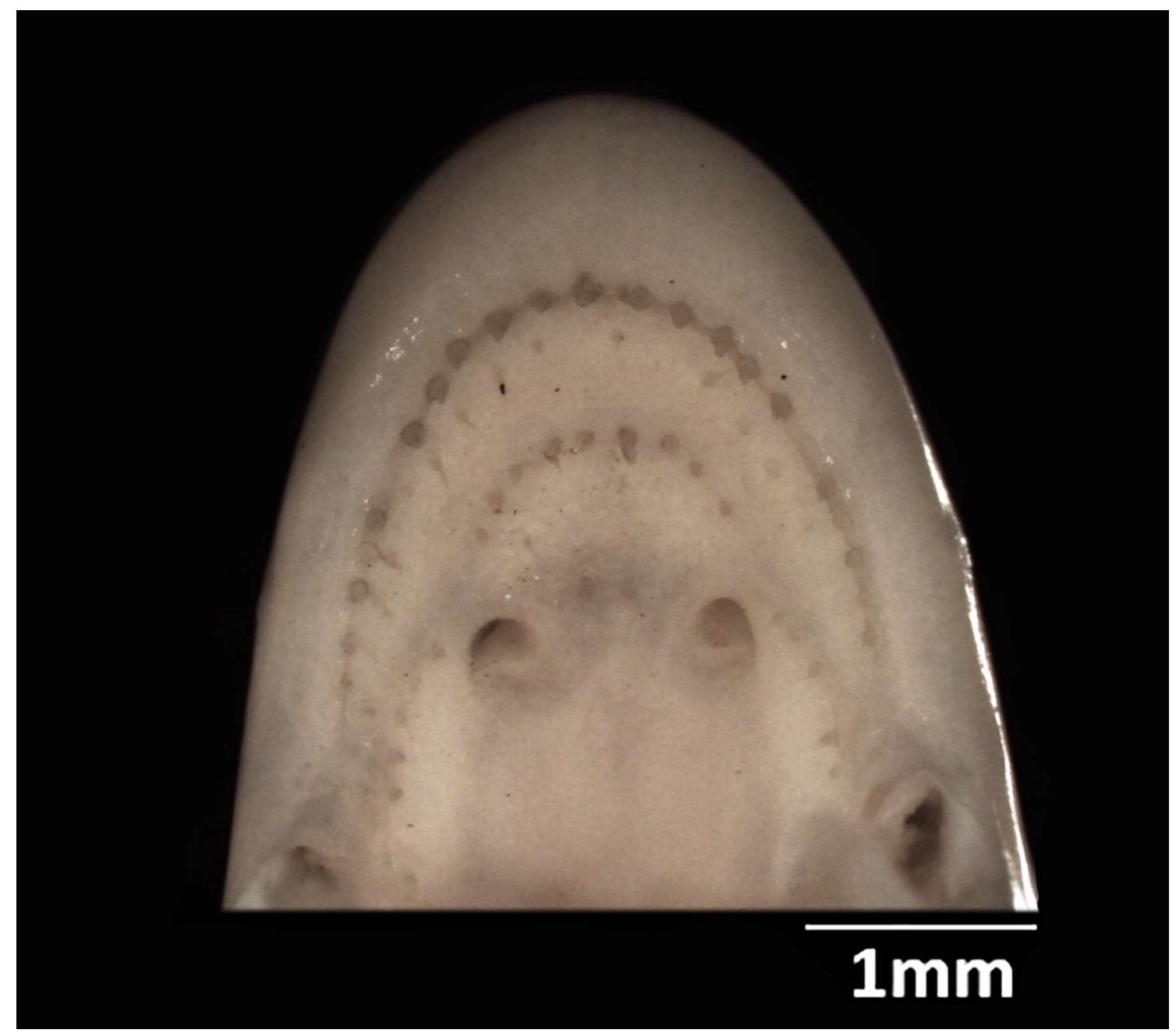

FIGURE 3. Palatal view of Brasilotyphlus dubium sp. nov. (holotype) showing disposition of tooth rows, diastema and choanae. Scale bars $=1 \mathrm{~mm}$. 
Coloration: In life, body pale purple; head pinkish. Venter and lateral surfaces, areas surrounding vent, nostrils and tentacles paler than dorsum. In preservative, body brownish; paler anteriorly than posteriorly in dorsal and ventral view. Ventral and lateral surfaces slightly paler than dorsum along the entire body. Areas surrounding the vent, nostrils, tentacles and lips less pigmented, as is the ventral surface anterior to the second collar.

TABLE 2. Morphometric (in $\mathrm{mm}$ ) and meristic data for the type series of Brasilotyphlus dubium sp. nov. [data from this study (MUFAL 13638-13642 and MPEG 7779), B. guarantanus [data from this study (MUFAL 10363 and 10379) and from Maciel \& Hoogmoed (2011)] and B. braziliensis [from Taylor (1968) and Maciel \& Hoogmoed (2011)]. * Holotype. Abbreviations are given in text.

\begin{tabular}{|c|c|c|c|c|c|c|c|c|c|c|}
\hline & \multicolumn{6}{|c|}{ B. dubium sp. nov. } & \multicolumn{3}{|c|}{ B. guarantanus } & \multirow{2}{*}{$\begin{array}{l}\text { B. braziliensis } \\
\text { range }\end{array}$} \\
\hline & $\begin{array}{l}\text { MUFAL } \\
13638^{*}\end{array}$ & $\begin{array}{l}\text { MUFAL } \\
13639\end{array}$ & $\begin{array}{l}\text { MUFAL } \\
13642\end{array}$ & $\begin{array}{l}\text { MUFAL } \\
13641\end{array}$ & $\begin{array}{l}\text { MUFAL } \\
13640\end{array}$ & $\begin{array}{l}\text { MPEG } \\
7779\end{array}$ & $\begin{array}{l}\text { MUFAL } \\
10363\end{array}$ & $\begin{array}{l}\text { MUFAL } \\
10379\end{array}$ & range & \\
\hline TL & 16.8 & 18.1 & 18.2 & 14.2 & 11.2 & 13.7 & 32.8 & 23.6 & $164-305$ & $147-260$ \\
\hline HW & 3.5 & 3.5 & 3.2 & 2.8 & 2.7 & 2.8 & 3.9 & 3.6 & $2.5-4.2$ & $2.7-5.1$ \\
\hline HWN & 1.9 & 1.9 & 1.6 & 1.4 & 1.3 & 1.3 & 2.1 & 2 & - & - \\
\hline HL & 4.9 & 5.1 & 4.7 & 4.6 & 4.2 & 4.6 & 5.1 & 5.3 & $3.8-6.2$ & 4.5 \\
\hline $\mathrm{HH}$ & 2.5 & 2.7 & 2.6 & 2.4 & 2.2 & 1.9 & 3.1 & 2.7 & $1.5-3.4$ & 2 \\
\hline SP & 1 & 1 & 1 & 1.1 & 0.9 & 1.1 & 1.0 & 1.2 & $0.8-1.5$ & 1.2 \\
\hline BW & 3.9 & 4.3 & 3.6 & 3.3 & 3 & 3.5 & 5.7 & 4 & $3.3-4.9$ & $3-6$ \\
\hline $\mathrm{BH}$ & 2.9 & 3.6 & 3.2 & 2.4 & 2.3 & 2.5 & 4 & 3.3 & $2.7-4.3$ & 2.8 \\
\hline WTR & 3.6 & 3.7 & 3.6 & 3 & 3 & 3.2 & 4.8 & 3.4 & $2.9-4.7$ & 3.1 \\
\hline $\mathrm{NN}$ & 1.3 & 1.5 & 1.2 & 1.2 & 1.1 & 0.9 & 1.8 & 1.6 & $0.9-1.5$ & 1.2 \\
\hline NMM & 0.9 & 1 & 0.8 & 0.8 & 0.7 & 1 & 1.1 & 1.2 & $0.6-1.2$ & 0.7 \\
\hline $\mathrm{NCM}$ & 3.2 & 3.3 & 3.3 & 3 & 2.1 & 3 & - & - & - & - \\
\hline $\mathrm{TN}$ & 1.6 & 1.6 & 1.6 & 1.4 & 1.2 & 1.5 & 2.0 & 1.9 & $1.3-2.4$ & $1.5-2.6$ \\
\hline $\mathrm{TT}$ & 3.2 & 3.2 & 2.7 & 2.4 & 2.3 & 2.3 & - & - & $2.2-3.4$ & 2.6 \\
\hline TMM & 0.3 & 0.3 & 0.3 & 0.3 & 0.3 & 0.3 & 0.4 & 0.4 & $0.2-0.5$ & 0.2 \\
\hline $\mathrm{TCM}$ & 1.3 & 1.4 & 1.7 & 1.6 & 1.1 & 1.5 & 1.5 & 1.6 & $0.8-1.6$ & 0.8 \\
\hline PMT & 21 & 22 & 23 & 22 & 22 & 19 & 19 & 18 & $17-24$ & $15-25$ \\
\hline PVT & 9 & 8 & 9 & 8 & 8 & 7 & 11 & 8 & $8-13$ & $8-12$ \\
\hline PT & 10 & 10 & 12 & 10 & 10 & 12 & 12 & 14 & $8-14$ & $10-14$ \\
\hline DT & 13 & 18 & 15 & 14 & 16 & 16 & 16 & 17 & $13-21$ & $13-18$ \\
\hline PA (CPA) & $125(123)$ & $128(126)$ & $123(121)$ & $129(126)$ & $128(125)$ & $\begin{array}{l}125 \\
(121)\end{array}$ & $\begin{array}{l}162 \\
(160)\end{array}$ & $\begin{array}{l}150 \\
(147)\end{array}$ & $151-170$ & $142-147$ \\
\hline $\mathrm{SG}(\mathrm{CSG})$ & $13(6)$ & $9(3)$ & $15(6)$ & $16(5)$ & $9(3)$ & $14(2)$ & 0 & 0 & $0-2$ & $23-36(4-7)$ \\
\hline AIV & 2 & 2 & 2 & 3 & 3 & 3 & 2 & 3 & $0-3$ & 2 \\
\hline
\end{tabular}

Variation and additional information from paratypes. Variation in some meristics and morphometrics is summarized in Table 2. The vertical terminal keel is less distinct in MUFAL 13642. In preservative, MUFAL 13641 and 13642 have steel grey body color, but the pattern of paler regions is similar to that observed on the holotype. The first collar of MUFAL 13641 and 13642 are less robust than observed in the holotype, forming an almost straight transition line from head to body. In paratype MPEG 7779, scales begin in the 90th groove, limited to a single and incomplete row of small scales, wider than long (e.g., $0.1 \times 0.3 \mathrm{~mm}$ ); in a single incomplete row at 109th groove (e.g., $0.1 \times 0.4 \mathrm{~mm}$ ) and in a complete row of ovate scales at 122 th groove (e.g., $0.5 \times 0.7 \mathrm{~mm}$ ). Except for minor details in their visibility, the nuchal grooves of all paratypes are as described for the holotype.

Etymology. The epithet dubium means "dubious", reflecting our doubt whether or not Brasilotyphlus should be considered a synonym of Microcaecilia. For nomenclatural purposes, the species epithet is considered a noun in apposition. 

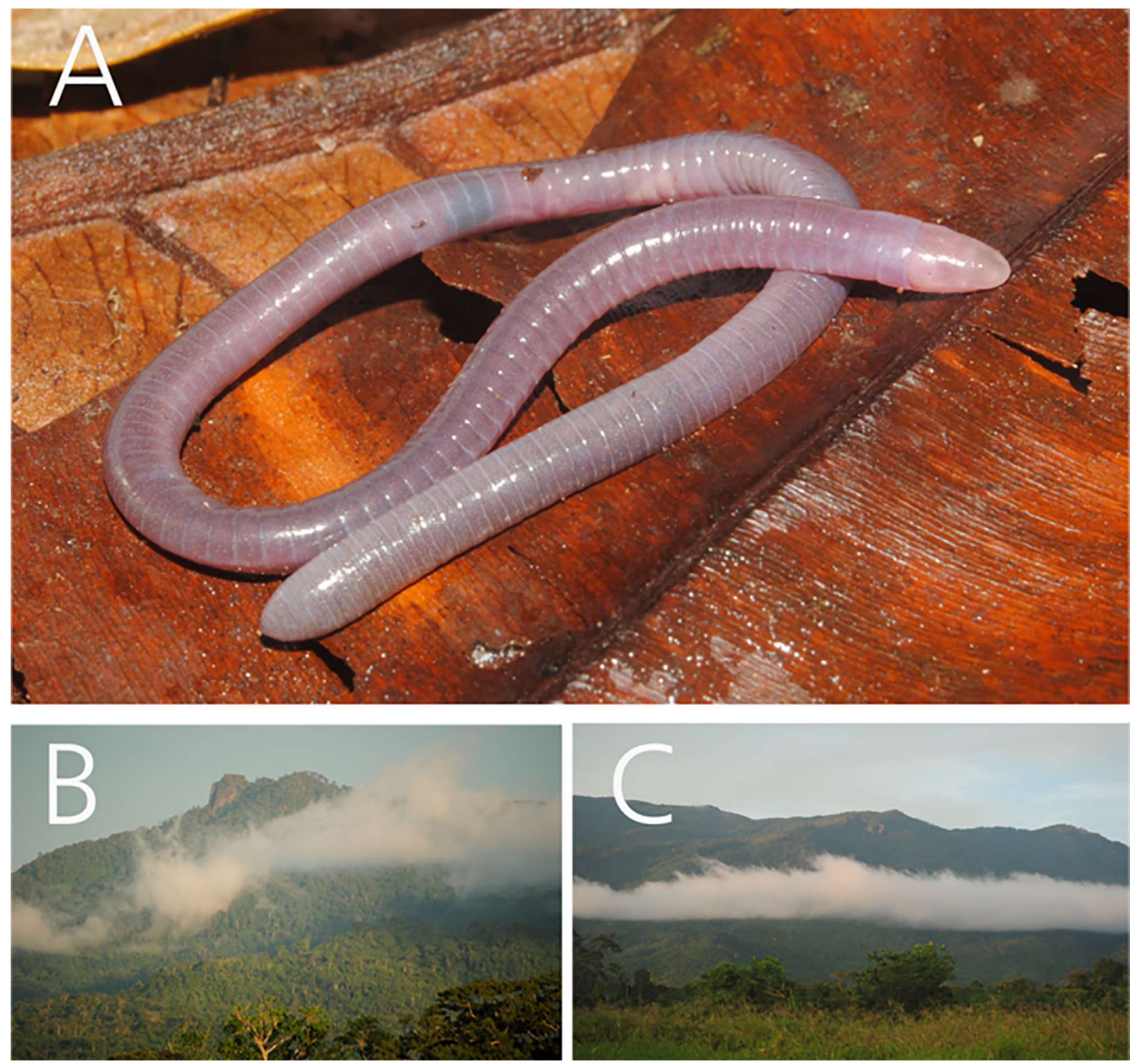

FIGURE 4. Brasilotyphlus dubium sp. nov. (A) Specimen from the type series in life in dorsal view. (B) Habitat at type locality, Serra da Maroquinha, Roraima, Brazil. (C) Habitat at Serra do Apiaú, Roraima, Brazil.

Phylogenetic analyses. The concatenated dataset consisted of 1,682 base pairs (bp) (605 bp of 16srRNA and $1,684 \mathrm{bp}$ of cytochrome b). After removal of $121 \mathrm{bp}$ in the 16SrRNA fragment (31-43, 218-284, 311-354) due to ambiguous alignment, 1,563 bp were used in the analyses. The families Caeciliidae, Typhlonectidae, Herpelidae, Indotyphlidae and Siphonopidae were each recovered as monophyletic with high support (Figure 5). Typhlonectidae and Caeciliidae were recovered as sister clades. The basal split within Siphonopidae is between a clade comprising Luetkenotyphlus brasiliensis (Lütken 1851) and Siphonops annulatus (Mikan 1820) (PP =1), and a clade comprising all sampled species of Microcaecilia [M. unicolor (Duméril 1863), M. dermatophaga Wilkinson, Sherratt, Starace \& Gower 2013, M. savagei Donnelly \& Wake 2013, Microcaecilia sp1. and Microcaecilia sp2.], B. guarantanus and B. dubium sp. nov. $(\mathrm{PP}=1)$. The latter two were recovered as monophyletic ( $\mathrm{PP}=1)$, but nested within a paraphyletic Microcaecilia (M. savagei and M. sp.2 are more closely related to Brasilotyphlus than to other Microcaecilia: $\mathrm{PP}=0.86$ ).

The maximum likelihood tree (not shown) is similar to our Bayesian phylogeny at well-supported nodes. The families Caeciliidae, Typhlonectidae, Herpelidae and Indotyphlidae were each monophyletic with high support (bootstrap value $[\mathrm{BS}] \geq 97$ ), and although Siphonopidae was recovered with moderate support $(\mathrm{BS}=79)$, the relationships among Brasilotyphlus and Microcaecilia were identical to those recovered in the Bayesian analysis. The AU test could not reject a monophyletic Microcaecilia (difference $-\operatorname{lnL}=1.77643$; AU test, $\mathrm{P}=0.2099$ ). 


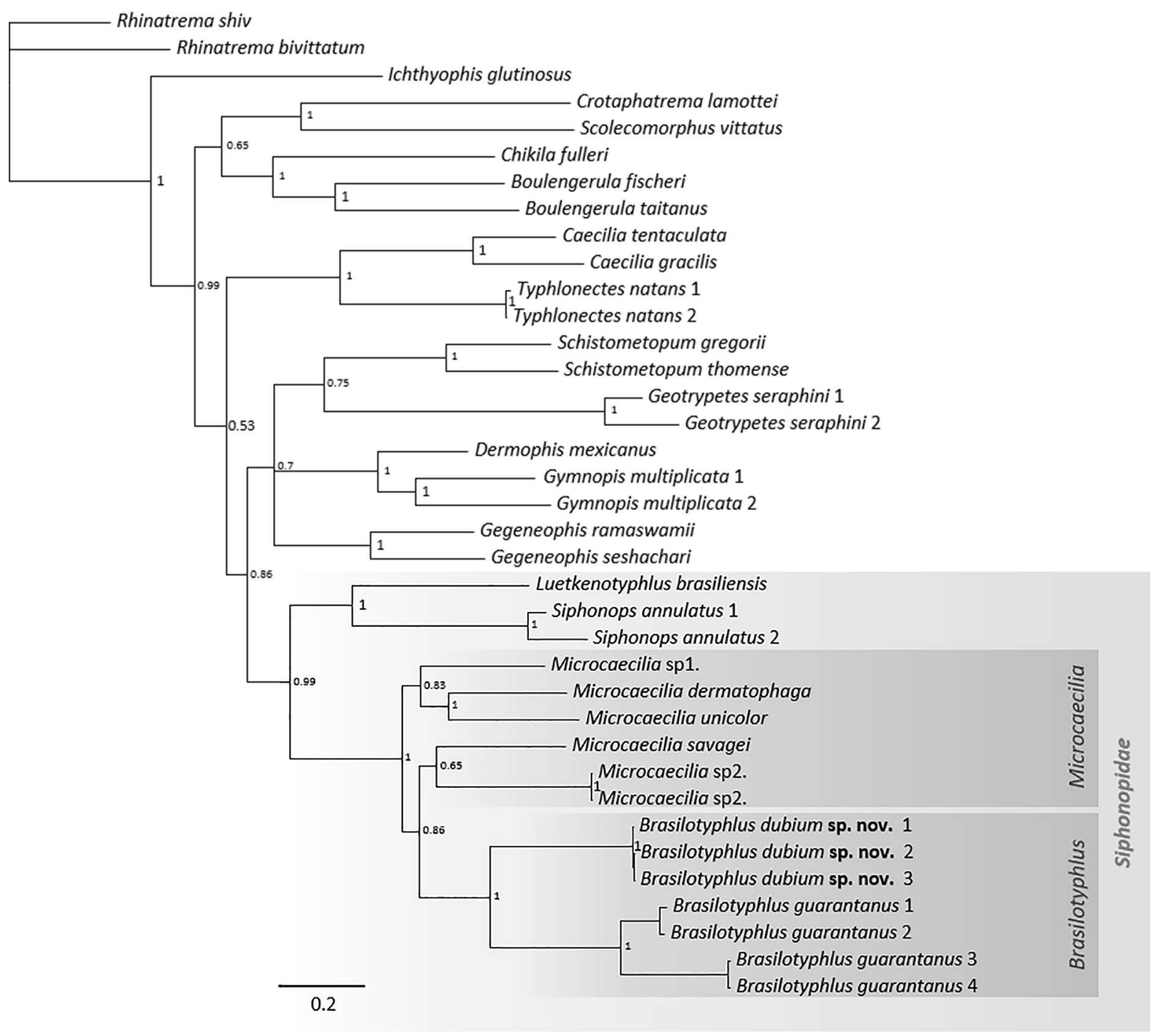

FIGURE 5. Phylogram obtained from Bayesian analysis (consensus by majority rule 50\%) using 1,683 base pairs of concatenated mitochondrial genes (16SrRNA and cytochrome b). Numbers at internal branches are posterior probabilities.

\section{Discussion}

To date, Brasilotyphlus had not been included in any molecular phylogenetic analysis and the doubts regarding its monophyly and relationship with Microcaecilia were, until this study, based only on morphological data. Our mitochondrial DNA-based phylogeny includes a monophyletic Brasilotyphlus nested within a paraphyletic Microcaecilia, suggesting that Brasilotyphlus could be considered a synonym of Microcaecilia or that Microcaecilia should be split. However, the AU test was unable to reject the hypothesis that Brasilotyphlus could be considered a synonym of Microcaecilia and, thus, we prefer to be conservative and retain both genera because (1) phylogenetic support for the position of Brasilotyphlus is moderate; (2) our topology tests could not reject a monophyletic Microcaecilia; (3) we were not able to sample the type species of either genus; (4) we inferred phylogenetic relationships only on the basis of two mtDNA genes. We suggest that additional molecular sampling (taxa, loci and genes) should be done to clarify the relationship between these similar genera of siphonopid caecilians.

The individuals of Brasilotyphlus dubium sp. nov. from Mucajaí municipality, state of Roraima, Brazil, were collected in two adjacent mountains (Serra do Apiaú and Serra da Maroquinha), both massifs are forest covered and isolated from each other by c. $4 \mathrm{~km}$ of secondary forests and pasture lowlands. The individual from Iracema 
municipality, state of Roraima, Brazil, was also collected in forest. Species of the genus Brasilotyphlus had been considered to be restricted to areas of rainforest (Rodrigues et al. 2004; Maciel et al. 2009). Therefore, we hypothesize that $B$. dubium may also be restricted to rainforest areas. However, more extensive sampling is necessary to understand the distribution and ecology of this new species.

\section{Acknowledgments}

This work benefited from financial support from Fundação de Amparo à Pesquisa do Estado de São Paulo (FAPESP), Fundação de Amparo à Ciência e Tecnologia do Estado de Pernambuco (FACEPE), and Conselho Nacional de Desenvolvimento Científico e Tecnológico (CNPq). Instituto Nacional de Pesquisas da Amazônia (INPA) and Wildlife Conservation Society (WCS) provided field support. The senior author had a master's scholarship granted for CNPq (proc $\mathrm{n}^{\circ}$ 130296/2015-5). We are grateful to ICMBIO for the permits. Cleuton Miranda, Sebastião Batista, Fernando Borges Gomes, Felipe Franco Curcio, Thayse Benathar and Catia Dejuste de Paula helped in the field. AF has benefited from an "Investissement d'Avenir" grant managed by the

Agence Nationale de la Recherche (CEBA, ref. ANR-10- LABX-25- 01). Field work on Serra do Apiaú was possible due to a grant provided by CNPq to SMS (556966/2009-0). TM thanks CNPq Fellowship (309904/20153). Mark Wilkinson and David Gower provided constructive criticism of the submitted manuscript.

\section{References}

Donneley, M.A. \& Wake, M.H. (2013) A new species of Microcaecilia (Amphibia: Gymnophiona) from Guyana, with comments on Epicrionops niger. Copeia, 2013, 223-231. https://doi.org/10.1643/ch-12-094

Duméril, A.H.A. (1863) Catalogue méthodique de la collection des batraciens du Muséum d'Histoire Naturelle de Paris. Mémoires de la Société Impériale des Sciences Naturelles de Cherbourg, 9, 295-321.

Dunn, E.R. (1945) A new caecilian of the genus Gymnopis from Brazil. American Museum Novitates, $1278,1$.

Fetzner, J. (1999) Extracting high-quality DNA from shed reptile skins: a simplified method. Biotechniques, 26 (6), 1052-1054. https://doi.org/10.2144/99266bm09

Hall, T.A. (1999) Bioedit: a user-friendly biological sequence alignment editor and analysis program for Windows 95/98/NT. Nucleic Acids Symposium Series, 41 (41), 95-98.

Huelsenbeck, J.P. \& Ronquist, F. (2001) MRBAYES: Bayesian inference of phylogenetic trees. Bioinformatics, 17 (8), $754-755$. https://doi.org/10.1093/bioinformatics/17.8.754

Kamei, R.G., Wilkinson, M., Gower, D.J. \& Biju, S.D. (2009). Three new species of striped Ichthyophis (Amphibia: Gymnophiona: Ichthyophiidae) from the northeast Indian states of Manipur and Nagaland. Zootaxa, 2267 (1), $26-42$. https://doi.org/10.11646/zootaxa.2267.1.2

Lütken, C.F. (1851) Siphops brasiliensis, an ny Art af Ormpaddernes (Caeciliernes) Familie. Videnskabelige Meddelelser fra Dansk Naturhistorisk Forening i Kjøbenhavn, 1851, 52-54.

Maciel, A.O. \& Hoogmoed, M.S. (2011) Taxonomy and distribution of caecilian amphibians (Gymnophiona) of Brazilian Amazonia, with a key to their identification. Zootaxa, 2984 (1), 1-53.

Maciel, A.O., Mott, T. \& Hoogmoed, M.S. (2009) A second species of Brasilotyphlus (Amphibia: Gymnophiona: Caeciliidae) from Brazilian Amazonia. Zootaxa, 2226, 19-27.

Mikan, J.C. (1820) Delectus Florae et Faunae Brasiliensis. Vindobonae: Antonii Strauss, 50 pp, 24 tabs. https://doi.org/10.5962/bhl.title.63994

Rodrigues, M.T., Azevedo-Ramos, C. \& Wilkinson, M. (2004) Brasilotyphlus braziliensis. The IUCN Red List of Threatened Species, 2004, $\quad$ e.T59500A11949756. Available from: https://doi.org/10.2305/ IUCN.UK.2004.RLTS.T59500A11949756.en (accessed 6 August 2017)

Miller, M.A., Pfeiffer, W. \& Schwartz, T. (2010) Creating the CIPRES Science Gateway for inference of large phylogenetic trees. In: Gateway Computing Environments Workshop (GCE), 14 Nov. 2010, New Orleans, LA, pp. 1-8. https://doi.org/10.1109/GCE.2010.5676129

Palumbi S.R., Martin, A.P., Romano, S., McMillan, W.O., Stice, L. \& Grabowski, G. (1991) The simple fool's guide to PCR. Special publication, Department of Zoology, University of Hawaii, Honolulu, 44 pp.

Posada, D. (2008) jModelTest: phylogenetic model averaging. Molecular Biology and Evolution, 25 (7), $1253-1256$. https://doi.org/10.1093/molbev/msn083

Rambaut, A., Suchard, M., Xie, W. \& Drummond, A. (2014) Tracer. Version 1.6. Institute of Evolutionary Biology, University 
of Edinburgh. Available from: http://tree.bio.ed.ac.uk/software/tracer/ (accessed 20 August 2017)

Ronquist, F., Huelsenbeck, J.P. \& Teslenko, M. (2011) MrBayes. Version 3.2 Manual: Tutorials and Model Summaries. Available from: http://mrbayes.sourceforge.net/mb3.2_manual.pdf (accessed 22 July 2017)

San Mauro, D., Gower, D.J., Oommen, O.V., Wilkinson, M. \& Zardoya, R. (2004) Phylogeny of caecilian amphibians (Gymnophiona) based on complete mitochondrial genomes and nuclear RAG1. Molecular Phylogenetics and Evolution, 33 (2), 413-427.

https://doi.org/10.1016/j.ympev.2004.05.014

Shimodaira, H. (2002) An approximately unbiased test of phylogenetic tree selection. Systematic Biology, 51 (3), $492-508$. https://doi.org/10.1080/10635150290069913

Stamatakis, A. (2014) RAxML version 8: a tool for phylogenetic analysis and post-analysis of large phylogenies. Bioinformatics, 30 (9), 1312-1313.

https://doi.org/10.1093/bioinformatics/btu033

Stamatakis, A., Hoover, P., \& Rougemount, J. (2008) A rapid bootstrap algorithm for the RAxML web servers. Systematic Biology, 57 (5), 758-771.

https://doi.org/10.1080/10635150802429642

Swofford, D.L. (2003) PAUP*: phylogenetic analysis using parsimony. Version 4.0 b10. Sunderland, Sinauer Associates, MA.

Taylor, E.H. (1968) The Caecilians of the World: A Taxonomic Review. University of Kansas Press, Lawrence, 848 pp.

Wilkinson, M. \& Nussbaum, R.A. (2006) Caecilian phylogeny and classification. In: Exbrayat, J.M. (Ed.), Reproductive Biology and phylogeny of Gymnophiona (caecilians). Science Publisher Inc., Enfield, pp. 39-78.

Wilkinson, M., O'Connor, A. \& Nussbaum, R.A. (2013) Taxonomic status of the neotropical caecilian genera Brasilotyphlus Taylor, 1968, Microcaecilia Taylor, 1968 and Parvicaecilia Taylor, 1968 (Amphibia: Gymnophiona: Siphonopidae). Occasional Papers of the Museum of Zoology, University of Michigan, 744, 1-12.

Wilkinson, M., Sherratt, E., Starace, F. \& Gower, D.J. (2013) A new species of skin-feeding caecilian and the first report of reproductive mode in Microcaecilia (Amphibia: Gymnophiona: Siphonopidae). PLoS ONE, 8, e57756. https://doi.org/10.1371/journal.pone.0057756

Wilkinson, M., San Mauro, D., Sherratt, E. \& Gower, D.J. (2011) A nine-family classification of caecilians (Amphibia: Gymnophiona). Zootaxa, 2874, 41-64. 